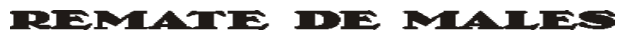

Campinas-SP, v. 38, n. 1, pp. 283-304, jan./jun. 2018

\title{
O discurso de posse de UM POETA- DIPLOMATA NA ACADEMIA BRASILEIRA DE LETRAS E OUTROS OPÚSCULOS
}

\author{
Éverton Barbosa Correia ${ }^{1}$
}

Resumo: Em 1969, João Cabral de Melo Neto tomou posse na Academia Brasileira de Letras com um discurso sobre a prosa de seu antecessor na cadeira 37, sob o título de "Elogio a Assis Chateaubriand". A partir desse escrito, intenta-se descrever algo acerca da vida cultural e literária brasileiras, considerando os lugares sociais ocupados pelo autor enquanto diplomata e acadêmico, mediados pelas relações pessoais ou familiares de que ele privou. De igual modo, serão depreendidas informações daquele texto a fim de explorar relações entre vida social e forma literária, levando em conta suas eleições temáticas e estilísticas, bem como sua compreensão sobre o desenvolvimento literário, notadamente o modernismo brasileiro. Para tanto, serão acionadas outras modalidades textuais, que sirvam de aparato ou contraponto ao discurso de posse, quais sejam, cartas, prefácios ou opúsculos pouco conhecidos do poeta que possam ampliar o entendimento de sua obra, ilustrada pelo poema "Vicente Yañez Pinzón".

Palavras-chave: João Cabral de Melo Neto; vida literária; formas liminares.

Quando do recebimento da Ordem do Mérito dos Guararapes, conferida pelo governo de Pernambuco em 1980, João Cabral de Melo Neto proferiu um discurso em nome dos demais agraciados com aquela comenda, entre os quais estavam o gaúcho general Golbery do Couto e Silva, os pernambucanos Capiba (compositor) e o também escritor e diplomata Mario Gibson Barbosa. Tendo o poeta sido eleito o orador do grupo, a tonalidade do seu discurso oscilava deliberadamente entre algo ponderado - como se prevê ao exercício diplomático - e algo pedregulhoso

1 Professor Adjunto do Departamento de Literatura Brasileira, Literatura Comparada e Teoria Literária do Instituto de Letras da Universidade do Estado do Rio de Janeiro - UERJ: evertonbcorreia@gmail.com. 
- como é constitutivo de sua poesia. Tal dualidade, mais do que sugerida, é explicitada ao longo de sua fala como um traço característico à sua expressão, da qual ele não poderia se esquivar diante de tantos notáveis, incluindo aí o chefe daquele estado, Marco Antonio Maciel, tomado como a persona do interlocutor a quem se dirigia retoricamente, sob o epíteto de "senhor governador", conforme o registro que se desdobra da seguinte maneira:

Eu é que devo a Pernambuco tanto o que me deu e me dá ainda, como matéria de poesia, como, pela insubserviência de sua história, o encorajamento que ele me deu e me dá para tentar a aventura de escrever; do mesmo modo como, por sua paisagem inexcessiva, o modelo de dicção que ele me dá para tentar a textura do que eu gostaria de realizar como poesia. [...] Sei que Vossa Excelência, que conhece bem a poesia que venho tentando escrever, sabe que, se ela é poesia de um antilírico, é também a de um antiorador, escrita mais para ser lida em voz baixa do que declamada, mesmo se o cenário que lhe oferecem fosse o do nosso querido Teatro Santa Izabel. Além do que, os trinta e cinco anos de carreira diplomática eliminaram de minha dicção qualquer vestígio de entonação tonitroante que, para muitos brasileiros, é característica dos gaúchos e dos nordestinos da Zona da Mata. (MELO NETO, 1981, pp. 5-7)

A publicação que encerra o discurso só foi editada no ano seguinte ao seu pronunciamento, pelogovernodaqueleestado, através da sua Secretaria de Turismo, Esportes e Cultura, num libreto em papel couchê, mas sem a indicação da tiragem. A qualidade do papel e a tiragem indiscriminada nos levam a crer que foram poucos os exemplares impressos e, por conseguinte, de pequena circulação entre os convivas daquela celebração, notadamente quem tivesse alguma relação com o governo. Até porque nenhuma das edições da prosa do autor coligiu o discurso, donde se presume o acesso limitado ao opúsculo, que adquire algum relevo devido ao valor literário que enseja. Pois não conheço outra parte da produção de João Cabral de Melo Neto, seja em prosa ou em verso, com trecho em que se explicite tão abertamente a ligação da sua voz lírica com a terra natal ou com o ofício desempenhado por ele durante toda a vida profissional, como se houvesse um laço estreito e irremovível entre o homem e sua poesia, tanto pela vivência junto àquela paisagem quanto pela sua conduta no trabalho. Conforme o caso, a poesia adquire uma dimensão extremamente material, uma vez que não pode ser desvinculada da experiência sensível em todos os âmbitos da existência, sem presumir aí uma correspondência exata, e sim uma simbolização elaborada e assumida como apropriada àquele sujeito. Sujeito que se quer vinculado ao seu tempo e ao seu espaço, ainda que sua universalização seja possível como um procedimento poético, por 
meio do qual a persona autoral se vê representada. Daí sucede que tudo aquilo quanto enxergarmos de referência à vida pessoal do poeta naquele momento de sua exposição pública, quando o escritor dobrara a casa dos sessenta, nem sempre fora perceptível antes de sua entrada na Academia Brasileira de Letras (ABL).

Como o que interessa, por ora, é depurar daquela escritura algo que possa ser desentranhado da vida social brasileira, a partir da vida literária, voltaremos à apreciação desse discurso mais adiante, para nos debruçarmos agora sobre um momento anterior, quando o autor ainda não tinha se tornado uma unanimidade crítica e acadêmica, justo para fazer o contraste entre o antes e o depois da sua consagração pública. Como é presumível, a diferença da exposição pública do escritor se deu com o passar do tempo, aos poucos e gradativamente, na representação social ou literária, quer consideremos sua prosa ou sua poesia. $O$ interesse aqui é, pois, o de costurar na vida cultural a sua obra e de ampliar seu valor de representação, para o que muito vem a calhar o perfil de alguém que representa o país artística e diplomaticamente. Diplomacia, Academia e literatura passam a convergir para a mesma dimensão simbólica imbricada na atuação de João Cabral de Melo Neto, o que vem a ser verificável pelo recorte da circunstância de sua entrada na casa presidida inicialmente por Machado de Assis. A partir daí, não custa imaginar que a rima entre diplomacia e Academia se estenda do plano literário para o cotidiano dos acadêmicos, que se desdobra na vida social brasileira, como se prevê.

A pretexto de insistir no dueto entre vida e obra, já é fato bem conhecido que houve um episódio bastante curioso na biografia de João Cabral de Melo Neto, pautado pelo seu afastamento do Itamaraty de 1952 a 1954, com todos os desdobramentos correspondentes, devido a motivações políticas. Sendo fato notório e publicado, será aqui abordado como ponto de exceção da trajetória do escritor, cuja consagração se consuma na década de 196o, quando da publicação do livro A educação pela pedra (1966) - tomado largamente como linha divisória na sua produção - e pela sua entrada na ABL em 1969. Esses eventos encadeados entre si delineiam no percurso artístico do poeta uma fatalidade histórica que incide sobre sua produção. Sem simular qualquer simetria entre vida e obra, descartada de antemão, cumpre que se especule algo acerca dos eventos que interferiram na vida cotidiana do autor e podem ser tomados também como sinais que apontam para uma silente mudança de comportamento no seu sujeito social, que repercute no posicionamento 
artístico, notadamente verificável na sua obra ulterior, que será apreciada através do desdobramento da figura de Vicente Yáñez Pinzón.

Para efeito de abordagem, tomaremos a Correspondência de Cabral com Bandeira e Drummond (2001) como registros da conduta do poeta-diplomata no seu ambiente de trabalho e no meio literário brasileiro, através da relação com seu primo e poeta Manuel Bandeira, a qual se estreita em virtude da publicação de Mafuá do malungo (1948), pautada por seu autor e por João Cabral, seu editor. Se a correspondência entre os dois autores será tomada como registro inicial das relações que resultaram no afastamento de João Cabral do Itamaraty, seu discurso de posse na ABL será alçado à condição de objeto literário autônomo - anúncio e contraparte do opúsculo Guararapes, ao qual já voltaremos - e, portanto, passível de apreciação particular, uma vez que encerra o percurso iniciado em fins dos anos 1940 até a década de 1960, quando da consagração institucional.

Sendo ocasionalmente o objeto preferencial de apreciação aqui o discurso de posse na ABL, intitulado "Elogio a Assis Chateaubriand", convém esmiuçar como ali se configura uma forma literária híbrida. Cambiante, na fronteira entre a representação social e a memória do escritor, sua matéria será destacada do estilo do homenageado, que reverbera nas palavras do orador circunstancial, bem como do autor que ele quis ser até aquela ocasião, e se desdobra artisticamente após o seu pronunciamento. Uma vez que a forma do "Discurso de posse" é indefinida literariamente, apesar do envoltório de protocolos em torno dos quais se move, aquele escrito será considerado como forma narrativa na primeira pessoa, através da qual podemos visualizar uma série de reduplicações: do sujeito narrador para o objeto narrado, no qual se projeta - a prosa de Assis Chateaubriand; da história pessoal que repercute no espaço público - a ABL; do estilo de outrem como prefiguração ou negação do próprio estilo; da identidade regional como um valor subjetivo e expressional do narrador, que, por sua vez, se transfigura em pessoa pública e em poeta.

A hipótese inicial é a de haver algum grau de articulação entre o que foi cogitado como traço distintivo da persona literária de João Cabral e sua conversão em estilo de escrita, que inscreve uma perspectiva deabordagem, destacando a repercussão da vida cotidiana no registro artístico. Esse truísmo ganha recurso aqui menos pela verdade que enseja do que pela estratégia que anuncia, qual seja, a de acionar parte da produção marginal de um autor para lançar alguma luz sobre o restante de sua obra, o que 
vem a ser outro truísmo, desentranhado daquele primeiro. Nesse jogo de espelho contra espelho, em que um truísmo anima outro, o saldo que se oferece é justo o de considerar como literatura o que não tem forma literária definida. Consequentemente, o que vier a ter valor simbólico aí não será depreendido diretamente da representação literária constituída, mas pode ser filtrado da representação social encenada num registro literário de circunstância definida, sem esquecer que João Cabral é um autor para o qual a forma tem um valor próprio. A encruzilhada entre circunstância definida e forma indefinida constitui um paradoxo interessante como estratégia de aproximação da obra cabralina, notadamente quando o autor se oferece como objeto de um evento público e institucional.

Diante desse quadro, a forma literária haverá de assumir um lugar a mais que o de constituinte verbal e expandir o horizonte da especulação estética, porquanto se coloca no limite de sua repercussão na história literária através da visualização de um escritor situado, ao par das circunstâncias sociais vivenciadas em seu entorno. Trata-se, portanto, de vislumbrar nas ambiências vividas por João Cabral o que subsiste de prefiguração formal da sua obra. Não pelo que se disse a seu respeito, inclusive por ele mesmo, mas pelo que está gravado nos interstícios do seu discurso de posse na $\mathrm{ABL}$, que soçobra como expressão literária reclusa e quase dispensável. Expressão literária essa que, paradoxalmente, faz figura de exceção no contexto de sua obra e só se verifica como parte de um episódio inaudito, porquanto tem sido amiúde ignorado pelos seus leitores, quando não rechaçado pelos seus admiradores, a exemplo dos concretistas, que cogitaram comparecer àquela cerimônia vestidos de preto, para caracterizar o luto da poesia, conforme refere seu biógrafo (CASTELLO, 2006, p. 110). Com tal negação das opções individuais do autor, o que se insinua é a obrigatoriedade da separação sistemática entre o escrito e a vida social, ou ainda, faz parecer que algum laço possível entre o feito e o dito ou escrito não coubesse na escritura de João Cabral; mais ainda, é como se o apagamento do feito ou do vivido pelo autor pudesse conferir outrovalor a seus escritos, que, afinal, soam como se não pudessem ser mediados por um sujeito social circunstanciado historicamente.

Meio a contrapelo do raciocínio, convém lembrar a vivência no Itamaraty décadas antes da consagração do autor, através da sua correspondência, na qual não faltam referências a outros autores brasileiros, a quem solicitara livros para publicação, a exemplo de Joaquim Cardozo, Ledo Ivo, Vinícius de Morais, Clarice Lispector e o 
próprio Bandeira, que inaugurou o selo Livro Inconsútil, após a edição de Psicologia da composição (1947), do próprio poeta-editor. Tendo solicitado um livro a Manuel Bandeira, foi disponibilizado a João Cabral o já citado Mafuá do malungo, que passou a pontuar a missiva entre os dois poetas, intensificada em torno de questões editoriais, fosse o tipo a ser impresso, o formato da portada, o título do livro e suas respectivas secções, ou, ainda, a qualidade do papel a ser timbrado. Aí entra a figura do superior imediato de João Cabral em fins de 1947.

o cônsul-geral Osório Dutra, que pelo visto parece ainda candidato à Academia, insiste em oferecer metade do papel de seu livro. Dei um contra, talvez ele se tenha esquecido. Não sei de seus sentimentos para com ele e se v. gostaria de aceitar isso dele. Em todo caso, se v. lembrar, escreva definindo a política que devo adotar no caso. (MELO NETO, 2001, p. 53)

A resposta foi prontamente enviada por Manuel Bandeira em carta datada de 16 de dezembro de 1947, com as seguintes alegações para a negativa:

Quanto ao oferecimento do nosso amigo, não aceite. Ainda que não houvesse outro motivo, gosto de dever a edição exclusivamente a você. Você não permite que eu contribua pagando o papel? Não seria nenhum sacrifício para mim. O nosso amigo não andou bem comigo. Quando o Temístocles [Graça Aranha] esteve à testa da Cooperação Intelectual, propôs meu nome para uma embaixada em Buenos Aires. E eu tinha aceitado, a contragosto, só por causa da persistência do Temístocles. Mas este deixou o cargo e o sucessor, despeitado porque não votei nele para a Academia, vetou a indicação de meu nome, alegando a minha falta de traquejo social, e substituindo-me pelo... Elói Pontes. Mas ele não sabe que eu soube do caso, e continua a me fazer rapapés... porque continua de olho na Academia. Não que guarde rancor, porque sei que no fundo é bom sujeito. Prefiro, no entanto, não lhe dever nada. (BANDEIRA, 2001, p. 54)

Embora a figura citada não compareça mais na correspondência entre os dois poetas, é certo que João Cabral não acatou a oferta registrada na carta anterior, devido à negativa já justificada. Afora a simpatia entre os poetas, havia o laço de parentesco entre os dois, assinalado em despedidas e post scriptuns ("p.s.") das cartas, que os enreda pelo ramo familiar Carneiro da Cunha, que se entronca no Cabral de Mello. ${ }^{2}$ Manuel Bandeira,

2 De igual modo, João Cabral dispunha de outros honoráveis primos no cordão de sua parentela, também membros da ABL: Joaquim Nabuco (pelo ramo Sousa Leão); Olegário Mariano (também pelo ramo Carneiro da Cunha); Mauro Mota (pelo ramo Cabral de Mello); Múcio Leão (pelo ramo Carneiro Leão). 
nos idos de 1947, uma vez que já tinha custeado por conta própria edições anteriores de seus poemas e tendo escolhido o editor para um livro cuja edição havia concorrência, decerto ele não precisava do papel nem dos rapapés do cônsul-geral do Brasil em Barcelona. Diferentemente de João Cabral, a quem a recusa do papel oferecido pelo superior imediato deve ter custado caro, se não naquele momento, ao menos posteriormente.

Quatro anos depois, Mário Calábria (cônsul-geral do Brasil) veio a interceptar certa correspondência de João Cabral, na qual se cogitava uma colaboração na revista do Partido Trabalhista Inglês. A despeito da relação de amizade que mantinha com o poeta, sem pestanejar repassou a correspondência a seus superiores do Itamaraty, acrescida de comentários insidiosos acerca da hipótese de a carta ser a prova cabal de que havia um golpe comunista fermentando no interior da diplomacia brasileira, onde estaria instalada uma de suas células. Como essa denúncia não surtiu efeito, Mário Calábria não hesitou em repassar a correspondência para os generais que exerciam cargos no governo de Getúlio Vargas, que, àquelas alturas, se via ameaçado pela onda comunista, mas também sem efeito. Para o episódio não ser enterrado de vez, repassou então a missiva a Carlos Lacerda, cujo propósito ferrenho era o de retirar Getúlio Vargas do poder. Viu ali uma ótima munição para sua metralhadora giratória, que alvejava a todos que sinalizassem alguma simpatia ao governo ou simplesmente pudessem servir de indício da sua fragilidade, como era o caso dos diplomatas brasileiros que estavam envolvidos no episódio, a saber, Amaury Banhos Porto de Oliveira, Antonio Houaiss, Jatyr de Almeida Rodrigues, Paulo Cotrim Rodrigues Pereira e o próprio João Cabral de Melo Neto (CASTELLO, 2006, pp. 116-117).

Naquele mesmo 1952, foram os cinco diplomatas afastados do Itamaraty e desprovidos dos seus proventos. João Cabral àquelas alturas já tinha dois filhos e mulher para sustentar, o que precipitou toda sorte de tentativas suas para suprir as demandas familiares; nesse sentido, ele até conseguiu alguns prêmios literários, a exemplo do oferecido pela cidade de São Paulo, por ocasião do seu IV Centenário, com júri composto por Antonio Candido, Vinícius de Morais e Rubem Braga. Ele também se ofereceu a Assis Chateaubriand para trabalhar como jornalista nalgum de seus jornais sob a alegação de que sabia escrever, ao que foi retrucado: "Ah, bom. Então não serve. Vá ser escritor que é melhor" (CASTELO, 2006, p. 74). Entre uma negativa e outra, foram se passando os anos e as publicações se multiplicaram num surto criativo em que, de uma cambulhada, só se 
acumularam os seguintes títulos: O cão sem plumas (1950); O rio (1954); Morte e vida severina (1956); Paisagens com figuras (1956); e Uma faca só lâmina (1956). Esses três últimos títulos foram publicados na coletânea que reunia sua obra até então e com os inéditos sob o título de Duas águas (1956). Embora $O$ cão sem plumas seja anterior à denúncia, é posterior às cartas citadas e reverbera em $O$ rio, que foi mentado e publicado no período em que João Cabral ficou fora do Itamaraty; bem como os demais livros foram todos concebidos e elaborados durante seu afastamento do serviço público, cuja volta sofreu a interferência de parentes, amigos e simpatizantes das mais variadas ideologias, fosse um Ledo Ivo ou um D. Helder Câmara (CASTELLO, 2006, p. 120).

Quando, finalmente, em 1954, foi reintegrado ao serviço diplomático, não retomou de pronto suas funções e cargos, porque foi designado a fazer pesquisas sobre o Arquivo das Îndias em Sevilha. Dali foi removido a Marselha e, depois, transferido a Madri, de onde foi nomeado chefe de gabinete do Ministro da Agricultura do governo Jânio Quadros e de seu primo, Romero Cabral da Costa, a quem dedicou o poema "O alpendre no canavial”, coligido no livro A educação pela pedra (1966). Assim, gradativamente foi-se recuperando sua condição diplomática anterior, sem que, com isso, passasse a usufruir da mesma liberdade que folgara antes, porque depois do processo de afastamento, mesmo absolvido, nunca deixou de ser visto sob suspeição, fosse pelos colegas de ofício, que não queriam se ver em maus lençóis, ou pelos militares, que assumiram o poder em 1964.

Não estranha, pois, que a essas alturas o escritor comece a cogitar seu ingresso na ABL, o que veio a se consumar em 1969. Seus interesses sofriam interferências de várias nuances, tanto pelo caráter moderado da Academia, quanto pela sua relação com o poder instituído - de onde viera boa parte de seus membros -, bem como pela representação social daquela casa, afora a projeção pessoal e os benefícios pecuniários. Quer por uma razão ou por outra, a ABL reunia todos os atributos para assegurar comodidade ao poeta, que ficou perambulando durante anos entre premiações conferidas por amigos e empregos negados por conhecidos, entre os quais estava Assis Chateaubriand, cuja cadeira na ABL João Cabral veio a ocupar e, por isso, coube a ele a celebração da memória de seu antecessor na cerimônia da posse, através de uma alentada reflexão sobre o estilo da prosa praticada nos jornais brasileiros. 
Sem descurar de todo o protocolo institucional constitutivo da entrada na ABL, João Cabral produziu naquela circunstância um escrito notável que ultrapassa em muito o limite da formalidade requerida, porquanto seu discurso de posse estava imperativamente aberto à vida cotidiana brasileira, social e literária, revelando muito do percurso e do estilo do autor que viria a substituir naquela ocasião. E embora João Cabral tenha gasto três páginas para dizer as razões que o levaram a apreciar o perfil do escritor Assis Chateaubriand - o que nos leva a crer que havia suspeitas de que a admissão do seu antecessor na ABL se devesse a motivações extraliterárias -, o propósito aqui é justo o de depurar do discurso sobre a prosa do jornalista as considerações que, eventualmente, incidam sobre a escrita de um autor para o outro, que, em negativo, vem a revelar algo da escritura do poeta no momento público da consagração acadêmica, a exemplo de quando especula sobre os porquês de o homenageado ser tomado como autor literário.

Ora, a hipótese de que quando um autor fala sobre outro acaba falando também de si não se aplica milimetricamente ao caso, uma vez que se deixar abandonar à sua maneira pessoal e informal não é exatamente uma propriedade de fácil reconhecimento na escrita de João Cabral. Em contrapartida, quando ele enxerga no jornalista um sujeito que se desdobra de si próprio, talvez haja aí algum princípio que possa ser aplicado à sua persona literária. Com a diferença de que Assis Chateaubriand dispunha de um veículo de informação que permitia seu desdobramento de dono do jornal em jornalista, ao passo que o veículo de João Cabral - a poesia - demanda que o autor se revele no sujeito poético, que não raro está revestido de um objeto no qual se projeta, poucas vezes inscrito num "eu", a exemplo da sua escritura sobre Assis Chateaubriand. Ocorre que sua projeção enviesada na escrita do jornalista não se restringe à colocação do sujeito, mas se estende à postura social e pública adotada por aquele sujeito circunstanciado, tal como refere.

O gosto da controvérsia explica também o feitio desse polemista: sua maneira de lançar-se nos debates sem meias-tintas nem meias-palavras; embaralhando-se neles apaixonadamente; entregando-se completamente a cada um deles, sem o cálculo do homem político, que sabe até onde quer e deve chegar, nem as reservas do homem de empresa, que receia ir além desse onde chegar: para só citar dois tipos sociais com que ele tanto conviveu, com cujos interesses sempre esteve associado, mas que o devem ter visto sempre, quando seu associado, desconfiadamente, como um verdadeiro espalha-brasas. (MELO NETO, 2008, p. 745) 
Seguindo o raciocínio já esboçado, consoante o qual há limites na identificação entre os autores, a ideia de João Cabral como um espalha-brasas não seria verossímil nem mesmo para seu mais ardente rival ou seu simpatizante mais ensandecido, se quisermos insistir no espelhamento. Tampouco João Cabral abriu mão de sua condição diplomática, fosse como ofício de servidor público ou como postura pública diante dos seus leitores. Ao invés, sempre se apresentava polido e ponderado, equilibrado e lúcido, mesmo diante das maiores adversidades sociais ou pessoais. $\mathrm{O}$ decoro e a compostura comparecem inapelavelmente ao longo de sua produção literária como um imperativo categórico irrevogável. E não terá sido diferente no seu discurso de posse na $\mathrm{ABL}$, mesmo quando sua polidez parece alvejar o jornalista homenageado, ele faz com que o defeito pareça aceitável e até se torne uma virtude.

Contudo, esse repórter que parece pensar somente a partir de fatos que observou, e escrever somente com os fatos que tem na mão, nunca foi o repórter que se apaga por detrás do que os fatos dizem. [...] Não é que o polemista e o repórter se alternassem, ora num ora noutro artigo. Eles se alternavam, mas dentro do mesmo artigo, dando-lhe um hibridismo que não era a menor originalidade de seu estilo de jornalista. O jornalista Assis Chateaubriand era um repórter de debate e um polemista que escrevia com coisas. (MELO NETO, 20o8, p. 746)

Aqui encontramos um termo que funciona como laço vivo entre os dois autores: "Falar com coisas", o que se converteu inclusive em título de poema posterior de João Cabral, coligido em Agrestes (1985). Mas, mais interessante do que destacar o ponto de afinidade entre os dois é um movimento perpendicular entre ambas as escritas. Se Chateaubriand era um jornalista híbrido de polemista e repórter, João Cabral é poeta misto de crítico e prosador, quando escreve poesia, e de crítico e poeta, quando escreve prosa. Em qualquer um dos casos, assinala-se uma subversão do gênero em que cada um se insurge, circunstancialmente. Portanto, é com a pena de escritor que ele desenvolve a imagem de Assis Chateaubriand, com a qual se identifica às vezes, muito embora seja outra a fibra de escritor que se desdobra de suas linhas quando alveja o autor no jornalista.

Assim, permito-me inverter os termos da tendência mais geral e dizer que Assis Chateaubriand foi um grande jornalista não por suas realizações nem por suas lutas, mas, antes de tudo, porque foi um grande escritor em prosa. E grande escritor não por haver escrito conservadoramente, mas sobretudo porque foi um escritor criador: um escritor que soube passar ao lado de todos os rolos compressores a serviço da uniformidade, e, portanto, da pobreza estilística, não pelo puro gosto de subverter regras, mas porque havia nele essa coisa 
especial, e rara, que revela, mais do que qualquer outra, o verdadeiro escritor: certa maneira pessoal de usar a linguagem que dá um sotaque original ao que escreve. (MELO NETO, 2008, pp. 247-248)

Não terá sido pequeno o empenho de João Cabral em converter o aspecto fortuito e circunstancial da crônica jornalística em grande prosa narrativa; bem como a conversão de um autor controverso e inaudito na condição de grande escritor deve ter lhe rendido alguma inquietação. A opção pelo aspecto prosaico de uma narrativa precária funciona como caso de exceção na circunstância celebrativa, porque faz os olhos se voltarem justamente para o que é acidental e até casuístico na fatura literária. Por outro lado, conforme o escopo, o condicionamento do grande escritor deixa de se pautar pela reprodução de fórmulas já convencionadas e passa pela especulação inaugural que se estabelece como crivo próprio, o que se aplica também à ABL, que soube acolher João Cabral, partidário confesso dessa condição na sua escritura.

Daí parecer aceitável depurar alguma especulação entre a funcionalidade da escrita que se queira original e a originalidade da função de seu discurso naquele contexto de pronunciamento, que não possibilita sua compreensão em abstrato e demanda um sentido apropriado para a circunstância. Qualquer que seja o sentido a ser depreendido da ocasião, estará inapelavelmente amparado pelas circunstâncias a que o autor esteve submetido, inclusive na condição de leitor do escritor que o antecedera na cadeira que veio a ocupar, tanto pelas opções estilísticas quanto estéticas ou ideológicas, sem fantasias prévias, conforme ausculta o outro.

\footnotetext{
Não pretendo que houvesse um projeto consciente de chegar a uma linguagem falada. Creio, mais bem, que ele chegou a ela por motivos psicológicos que estão, mesmo, no oposto de qualquer "vontade de estilo". A linguagem falada se foi desenvolvendo nele à medida que foi mudando sua situação de jornalista: à medida que esta lhe foi dando uma maior liberdade como prosador. Mas seu estilo não é em nada um estilo construído, planejado: é simplesmente o estilo que ele achou quando sua situação de jornalista-dono-de-jornais lhe permitiu escrever, não em estilo de jornal, mas da maneira como bem lhe parecesse. Ora, ao poder escrever como bem lhe parecesse, Chateaubriand se viu escrevendo como falava. (MELO NETO, 2008, pp. 748-749)
}

A primeira informação a destacar do trecho recortado é o grau de vizinhança entre a sensação física da fala e seu desdobramento em traço estilístico individual. Não por opção ideológica ou programática, mas por uma dimensão, por assim dizer, residual do ofício e ao exercício desse ofício bem particularizado, que se desenrola do dono do jornal 
para o jornalista. Ora, se é o exercício da profissão que propicia a dicção particular do escritor, não há, por tabela, vínculo estreito entre o resultado atingido e o objetivo programado, que fica à mercê das circunstâncias e da condição do jornalista-dono-de-jornal. Daí decerto descolaremos outro ponto de discordância entre a produção escrita do jornalista e a do poeta naquele momento de sua posse na $\mathrm{ABL}$, uma vez que este se pautava deliberadamente por um projeto de escrita, o que não o levou a se afastar ou a ignorar as condicionantes da escrita do outro. Até porque vai gradativamente se aproximando daquela estratégia de escritura na maturidade - quando pauta suas composições pelo timbre da sua voz o que é verificável na sua poesia, mas também na sua prosa, tal como já foi sinalizado no início, a propósito da leitura do discurso Guararapes, ao qual voltaremos mais adiante.

Aliás, a diferença entre os posicionamentos dos autores é que permite à prosa cabralina atingir um grau de espontaneidade talvez até então inatingíveis pelo autor, como se constata pelo fraseado do seu texto. $\mathrm{O}$ estilo de Chateaubriand, ao invés, desenvolve-se através de um feitio individual que se particulariza em múltiplas nuances que vão desde uma espontaneidade expressiva radicada na oralidade do autor até sua inscrição social, identificada pela sua condição híbrida de proprietário de jornal com a de funcionário da empresa que produz textos, ordinária e cotidianamente. Daí a inscrição social do autor poder se estender na compreensão de cultura do jornalista com a qual o poeta se identifica, quando diz:

O segundo aspecto [no estilo de Chateaubriand] é a crescente presença, em sua linguagem de jornalista, da linguagem do Nordeste. Quando liberado dos espartilhos da convenção jornalística, a que o obrigava o fato de escrever para jornais dos outros, Chateaubriand encontra, escrevendo, sua maneira de falar, sua voz física: ora, por debaixo dela estava o Nordeste, que era o timbre e a dicção dessa voz. Foi a presença dessa linguagem do Nordeste, viva ainda nesse nordestino depois de tantos anos de ausência, que a muitos de seus leitores de fora da região parecia, às vezes, gosto pelo puro pitoresco, senão expressões inventadas por um amor gratuito pelo pitoresco. Entretanto, sua maneira de escrever é a maneira de falar da sua região, tanto quanto os tons de humor, extremados em caricatura, que ele empregou frequentemente. (MELO NETO, 2008, p. 750)

Não deixa de ser controverso para nossos dias que se queira imputar a um estilo a linguagem do Nordeste. Nem tanto pela variação terminológica que rodeia os conceitos de "estilo" e de "linguagem", mas muito mais pela pressuposição de um vínculo indivisível entre a linguagem e a região, 
supostamente portadora de uma unidade a conferir identidade a seus rebentos. Desbastadas as hipóteses de que, se houver um Nordeste como divisor regional, não se tratará de um limite geográfico ou cultural uno, e a de que identidade sempre se constrói com algum gosto e conforme o interesse, é preciso assinalar que a locução adjetiva "do Nordeste" e o adjetivo "nordestino" soam ao longo do seu discurso como instâncias valorativas do estilo de Assis Chateaubriand, a quem tinha ali a função institucional de homenagear. A circunstância, então, pedia que se enxergasse no outro autor princípios que servissem para justificar a sua homenagem.

Tal como vimos, se, num primeiro momento, a valoração do homenageado se dava através do reconhecimento de certa coloquialidade e espontaneidade presentes na sua escritura, agora a valoração será extensiva para as marcas presentes na sua expressão linguística que concorrem para a identificação do sujeito ali inscrito, de onde se pode depreender a existência de outro vínculo entre o estilo e o sujeito. Se for possível, por que tal laço tem de ser atado entre os cordões do idioleto individual do autor, passando pelos ilhoses que demarcam a variação regional? Trata-se de uma questão que exige algum vagar a respeito.

Sendo a hipótese bastante sedutora, perde ela sua força quando confrontada à condição irrevogável de que o mesmo procedimento não seria aplicável a outros autores de regiões distintas, pelo simples fato de que não tenho registro de alguém empenhado em delimitar um sotaque sudestino, centro-estino, sulino ou nortino. Tampouco parece plausível ou espontâneo que alguém queira ser identificado pelo adjetivo que qualifica sua região de origem no Brasil, já que a reflexão sobre o assunto fica restrita a uma única: a Nordeste. E já que o discurso regional não pode ser extensivo a todas as regiões do Brasil, a restrição da identificação linguística a apenas uma região perde sua legitimidade argumentativa, de vez que não pode ser comparada às demais. $\mathrm{O}$ caráter exclusivista da afirmação de João Cabral se fragiliza porquanto não pode ser reprodutível a outras circunstâncias discursivas em que autores oriundos das outras regiões pudessem se valer do mesmo princípio. A impossibilidade de reproduzir o procedimento aplicado ao estilo de Assis Chateaubriand enfraquece o argumento de João Cabral, enquanto expediente válido para conferir valor conceitual à sua apreciação. Apreciação que subsiste como vetor indicativo da expressão individual do autor através das particularidades lexicais identificáveis no seu texto, mas sem lhe conferir 
universalidade, resvalando em algo que se faz, na verdade, circunstante, quando na verdade o que se pretende é um conceito ou uma definição que o identifique.

Identidade que no caso da poesia brasileira nunca encontrou sujeito estruturado, conforme assinala Alcides Vilaça (1993, pp. 145-146), no seu artigo "Expansão e limite na poesia de João Cabral", quando observa: "nossa poesia moderna não conheceu afirmação da personalidade íntegra ou estabilizada: tem vivido sobretudo nas perspectivas da multiplicação e do contraditório". E João Cabral de fato não foge à regra, nem como poeta nem como prosador, uma vez que sua prosa é pródiga em fissuras, como se vê. Interessante é notar que a dilaceração do sujeito poético para a personalidade literária pareça atingir a ambos, a João Cabral e a seu duplo, circunstancialmente representado por Assis Chateaubriand, uma vez que o poeta pernambucano sempre se projeta nos objetos de sua exploração, sem lhes desfigurar de todo e às vezes até dando a impressão de que estão mais vivos sob a mediação de sua escrita. Mas, como nem tudo ésó projeção, a pretexto de abstrair a materialidade da obra em detrimento de alguma abstração outra, algo semelhante haverá de acontecer com sua tentativa de inscrever o autor Assis Chateaubriand na história literária, quando o aproxima por dedução do Modernismo brasileiro, como um movimento literário com o qual poderíamos identificar sua prosa jornalística, seja por uma indicação etária - o que é inquestionável - ou por uma indicação estilística - o que é bastante questionável, conforme se segue.

Nem me causaria surpresa saber que sua atitude em relação a muitos dos princípios do Modernismo tenha sido de incompreensão. Mas não se pode deixar de fazer notar que sua prosa foi ganhando personalidade paralelamente à obra dos escritores de 1922. Temperamento que nada tinha do puritanismo do pseudo-clássico da época, inconvencional até no comportamento, espírito curioso e sem preconceitos, é impossível que Chateaubriand não tenha sido marcado, senão pelas teorias, sim pela maneira de fazer, primeiro, dos modernistas, que lutavam para criar uma literatura que usasse uma língua mais aproximada da que se usa no Brasil. (MELO NETO, 2008, p. 751)

De acordo com o entrecho, sendo incompreensiva a visão de Assis Chateaubriand em relação ao Modernismo, ao afirmar que não sabia da opinião do jornalista sobre o movimento literário, João Cabral deixa claro que em vida não houve adesão do autor àquela causa ou àquele projeto, a não ser pela fatalidade histórica que os aproxima, da qual nenhum autor pode fugir, e que o próprio João Cabral rejeita para si mesmo, quando associado à "Geração de 45". Valendo para o outro autor, João Cabral não 
aplica o raciocínio para si próprio, o que só dá a ver que já àquelas alturas, nos idos de 1969, o Modernismo funcionava insofismavelmente como princípio de afirmação, como se o desejo de usar a língua numa escrita mais aproximada da fala fosse um imperativo categórico exclusivamente modernista. Mais ainda, é como se houvesse uma ligação entre Chateaubriand e os modernistas brasileiros, independentemente até das relações concretas que eles mantiveram entre si.

Com isso, só se evidencia que o critério tão bem decantado por João Cabral - quando do levantamento do desempenho estilístico de Assis Chateaubriand como autor que trabalha no jornal - não se sustém, ao menos quando o aproxima do movimento literário, porque carece da base empírica a ser fornecida pelas fontes primárias e pelos registros da sua vida social ou literária. Ao invés, faz parecer que a aproximação entre o autor e o movimento literário poderia se dar em abstrato, alheia à contaminação dos artefatos e registros cotidianos, sem os quais a afirmação autoral e a do Modernismo se dariam previamente e sem o crivo da objetividade do cotidiano vivido pelo autor ou pelos simpatizantes do movimento, o que não deixa de ser uma mistificação da história de um e de outros.

Para fechar a análise, gostaria apenas de retomar a expressão que Assis Chateaubriand aplicou à sua cadeira, quando de sua entrada na ABL, e que João Cabral retoma para lembrar a vivência do jornalista naquela casa, qual seja, "Paiol de pólvora". O mesmo "Paiol de pólvora" sobre o qual João Cabral veio a se sentar, não sem aviso, porque sabia que aquele autor se referia a aspectos políticos e literários, que João Cabral atualizava. No caso da política, para conseguir uma posição mais cômoda, tal como veio a usufruir até o fim dos seus dias, já que, depois de seu afastamento do Itamaraty, a sombra dos militares jamais o deixaria em paz, até sua entrada na ABL; no caso literário, pela potência expressiva e pelo ensejo à reflexão que sua escritura suscita, notadamente quando é o caso de sua prosa ensaística, que, já experimentada anteriormente, desdobra-se em outras circunstâncias, como visto.

Com efeito, é preciso assinalar que a prosa de João Cabral, mesmo quando não é propriamente ensaística - seja quando ele faz um prefácio ou quando profere um discurso mais abrangente -, mesmo aí sua escrita oscila entre o registro histórico e uma composição simbólica, para a qual convém sempre acionar a matéria pernambucana sob o anteparo de uma dicção expressiva que conjuga muito bem uma experiência histórica que o autor atualiza e uma modalidade expressiva que tende a conferir 
universalidade ao evento particular descrito. Este é alçado pelo autor à condição de elemento representativo de uma coletividade e que se opõe à história oficial, porquanto ele simpatiza com Pernambuco, quando não se identifica com o estado. Assim, sua sensibilidade dissidente e sua subjetividade refratária ao seu lugar de pronunciamento estão projetadas nos objetos circunstantes que ele aciona e, por conseguinte, adquirem valor simbólico, para o qual a história se oferece como alentado esteio, porque o símbolo parece mais bem sedimentado quando se enraíza numa circunstância histórica e o autor o faz parecer, assim, mais lógico e legítimo, embora não se identifique de todo com a circunstância que descreve.

Como se viu, quando João Cabral assume a cadeira da ABL, ele ainda tem uma pulsão de escritor indômito e desgarrado das agremiações ou filiações estético-programáticas. Daí vem parte do seu desejo de análise da prosa de Assis Chateaubriand, um corpo estranho na tradição literária brasileira, que não encontrou eco em momento posterior, a não ser por ocasião do recebimento da Ordem do Mérito dos Guararapes, conferida pelo Governo do Estado de Pernambuco em 1980. Portanto, uma década depois de João Cabral ter se tornado imortal pela ABL e de já ter publicado mais dois livros - Museu de tudo (1974) e A escola das facas (1980) -, a partir de quando se verifica uma silente transformação na impostação de sua voz, que passa a mimetizar a si mesma, tomada já de si como modelo de representação a incidir sobre o código literário vigente.

Curioso é, ainda, notar alguma similaridade na postura do autor em ambos os momentos de consagração, a despeito da significação diversa que os separa, seja de âmbito nacional ou estadual. Na celebração nacional o objeto de análise é a prosa do imortal que o antecedera, mais conhecido pela sua intervenção na vida social e cultural do país do que nas letras propriamente, ao passo que na celebração estadual o objeto de culto é o Pernambuco todo, o que demanda maior poder de síntese e prejudica a análise. Não por acaso o discurso proferido a um público amplo, sem ser exclusivo a literatos, tem outras pretensões para além da oportunidade de louvar uma prosa desconhecida sob o "Elogio", que caracteriza o título e o corpo daquele seu discurso anterior.

Por outro lado, referindo os limites da sua voz de diplomata, o poeta vai falar de Pernambuco através de seus momentos seminais - tal como está gravado na memória provinciana mais remota o episódio da batalha dos Guararapes -, aludindo aos nomes dos insignes capitães, 
para chegar ao nome daquele que talvez tenha sido o primeiro a vislumbrar Pernambuco sob luminosidade tangencial, mesmo antes do descobrimento do Brasil, que foi Vicente Yáñez Pinzón. O próprio poeta refere que seu conhecimento sobre o viajante se deu por ocasião de suas pesquisas no Arquivo das Îndias, em Sevilha, segundo descrição em dois opúsculos, em Guararapes (1981) e no "Prefácio" de Pernambuco: imagens do Nordeste (1988), que também será apreciado pelas considerações que o poeta faz sobre o navegante que primeiro viu Pernambuco com novos olhos. A ideia é a de mostrar como o poeta singulariza e cristaliza aquela visão primeira como ato fundador da representação de Pernambuco, que ele queria presente naqueles seus dias, fosse pela descrição do episódio na prosa ou em versos.

Antes de chegarmos aos seus versos sobre o viajante, vejamos suas considerações prosaicas sobre quem primeiro viu Pernambuco com a lupa de poeta. Para fazer a menção retrospectivamente, comecemos pelo opúsculo publicado por último, para depois chegar ao anterior, cujo confronto com a descrição poemática se faz oportuno. Por ora, o que nos interessa são os comentários sobre a paisagem, presentes no texto do já citado "Prefácio" ao livro Pernambuco: imagens do Nordeste, que recupera título de poema de Joaquim Cardozo e que reúne composições de vários outros poetas ocupados com a paisagem nordestina, incluindo aí o próprio João Cabral de Melo Neto, presente no volume como poeta ilustrador das imagens fotografadas e como prefaciador.

A poesia que se interessou por Pernambuco não ficou nessas cidades do litoral. Não esqueceu nunca a Zona da Mata, com seus mangues e seus falsos desertos de verdes canaviais, as sombras de um azul líquido de suas árvores fruteiras, e o que sobra hoje em pedaços esfiapados, nos altos "cuscus", da antiga mata tropical, devastada desde os tempos da Capitania para a implantação dos partidos de cana, restos talvez preservados porque até o mais alto não pode chegar o arado e o burro cambiteiro. A poesia sobre Pernambuco não esqueceu tampouco o Agreste que a sucede e já anuncia a Caatinga ou Sertão mais árido ainda, e que, juntos, constituem mais de dois terços do território de Pernambuco. De onde vem a atração que exercem sobre poetas paisagens tão contraditórias? [...] Essa paisagem muito deve ao "sol inhabitável" que a preside, à qualidade da luz que a ilumina (e que na faixa do litoral recebe do mar algo que a matiza). "La tierra de más sol de la Tierra”; creio que foram estas as palavras do navegador Vicente Yáñez Pinzón ao esclarecer diante do Conselho de Índias de Castela, certos detalhes da rota que se seguira em uma de suas viagens e que o levou àquele "Cabo de Rostro Hermoso" onde havia chegado em Janeiro de 1500, e que é nosso atual cabo de Santo Agostinho. (MELO NETO, 1988, p. 7) 
Não deixa de ser curioso que as imagens perseguidas escorrem do espaço físico, urbano ou agrário, geograficamente determinado para se incrustar em registro histórico impreciso e que contradiz a historiografia vigente. Pela imagem por ele visualizada, nota-se que o prefaciador do volume vê na poesia de seus coevos a mesma experiência histórica atualizada, que, na condição de poeta, João Cabral de Melo Neto, mais do que celebrar, desejava gravar na memória de seus leitores; ou, ainda, cavar uma tradição de conduta, de experiência e de pensamento que se transfere para as coisas do espaço e do tempo registradas em imagens, tal como está enunciado em versos subscritos e retirados de um dos seus poemas enfeixados no volume A educação pela pedra (1966), que é “O sol em Pernambuco" e que vai reverberar no prefácio: "Pinzón diz que o cabo Rostro Hermoso/ (que se diz hoje de Santo Agostinho)/ cai pela terra de mais luz da terra/ (mudou o nome, sobrou a luz a pino)" (MELO NETO, 2008, p. 331). Quando o escritor volta ao assunto, nos idos de 1988, no seu "Prefácio" a Pernambuco: imagens do Nordeste, só dá a dimensão de que o navegador espanhol e o Cabo de Santo Agostinho, que referendam a luz de Pernambuco, aureolam o rol de suas ideias fixas, obsessivamente. Não por acaso, teriam comparecido naquele mesmo discurso de recebimento da comenda pernambucana, proferido em 1980 e publicado em 1981, quando a história da capitania, que foi província e se transformou em estado, é tomada em seu valor simbólico.

A paisagem de uma batalha, e por isso devem ser perdoados os cronistas dos Guararapes, por melhor escritor que seja o historiador que a tenta dar a ver, é sempre uma paisagem impessoal, não em colinas mas em curvas de nível. [...] Mas a partir do pouco que de concreto eles deixaram cair no curso de suas narrativas, é possível reviver os Guararapes, relê-los em seu contexto, no contexto dessa paisagem de Pernambuco que Vicente Yáñez, em depoimento ante o Conselho das Îndias, em Sevilha, quando se tratou de sua chegada a estas bandas, chamou a terra de mais luz da Terra. (MELO NETO, 1981, p. 12)

Para efeito de comparação entre a poesia e a prosa cabralinas, vejamos como o autor havia gravado em versos a mesma informação, ainda no ano de pronunciamento desse discurso e no ano anterior à sua publicação, impressa pelo Governo do Estado de Pernambuco, que reverbera a composição antilírica abaixo. Antes disso, vale frisar que a figura do navegador havia aparecido em dois de seus textos em prosa publicados na década de 1980, assim como no poema "O sol em Pernambuco", coligido no livro A educação pela pedra (1966), mas a imagem ganha maior relevo indiscutivelmente na exploração que o poeta faz da figura no poema, cujo 
título quase esquecido é o nome do viajante espanhol "Vicente Yáñez Pinzón”. Embora publicado no volume A escola das facas (1980), que é todo encharcado de imagens pernambucanas imantadas pela sua experiência familiar e é dedicado a seus irmãos, nem por isso o poema é portador de menor acabamento artístico, a considerar o apuro da composição que dilacera séculos e o espaço onde o poeta se criou e forjou sua sensibilidade.

Vicente Yáñez Pinzón

Ele o primeiro a vê-lo, e a vir,

(na barra do Suape) ao Brasil,

não deixou lá quandos nem ondes:

só anos depois confessou-se.

Porque aquele que então confessa

"a terra de mais luz da Terra"

não prendeu muito tempo os pés

do homem de Palos de Moguer,

Moguer, da clara Andaluzia,

Caiada em Cádiz, em Sevilha?

Ele se foi só porque não?

Por ver-se na demarcação

de Portugal? Ou porque aquela

luz metal, que corta e encandeia,

acabaria enceguecendo

mesmo o andaluz mais sarraceno?

Ele, talvez, nessa luz tanta

tenha pressentido a arma branca

com que em tudo se expressaria

a gente que de lá, algum dia.

(MELO NETO, 2008, p. 415)

Para efeito de contraste, eis aí o poema como fonte, não só como um artefato linguístico que se presume parte de uma cultura, mas como registro de uma voz que se elabora literariamente e tematiza a história - que é atualizada no texto. A voz se faz portadora de uma dicção baixa, para se interpor deliberadamente ao fraseado largo da compulsão retórica 
ou do efeito anestésico da falação corrente ou da certeza inviolável, que se vê ameaçada em face dessa construção discursiva, a exibir-se como fabricação da história. A despeito de o poema ser portador de forma literária que singulariza a expressão do autor, respaldada por outros artefatos de linguagem e registros, pode também ele ser tomado a partir de agora como uma referência, senão histórica ou cultural, ao menos dos princípios que animam o estilo do autor, para o qual "a arma branca” vem a ser um referente que se faz um traço distintivo seu, seja tomado como uma faca ou uma pedra. Portadora de uma escritura para a qual a matéria pernambucana éuma marca, que exerce funçãovalorativa da representação que engendra, porquanto está ancorada na história. A história observada no contrafluxo também faz evidenciar que ser pernambucano nem sempre implica ser regional ou ser nacional, embora pernambucano João Cabral nunca deixe de ser e é sempre como pernambucano que ele fala, à revelia até do que Pernambuco venha a significar. Independentemente de ser regional ou nacional, pernambucano João Cabral é, como se o pedaço de terra que o identifica pudesse ser decalcado dos sentidos que lhe foram atribuídos historicamente e pairar numa zona etérea, cuja significação é dada pelos seus traços de expressão, que historicizam a própria semântica verbal construída ali e só se historicizam porque ele gravou em versos a imagem primeira daquele que vislumbrou a vida pernambucana antes mesmo de ela existir, antes mesmo de Pernambuco ser nomeado e vivido por gente lusa.

A limpidez do olhar virginal de quem viu pela primeira vez o que ainda não existia para um dado grupo - e, portanto, não existia como matéria pública - é anterior à sua atribuição simbólica e, por conseguinte, esse olhar não pode ser valorado ideologicamente, embora possa ser objeto estético que se faz histórico. E é esse olhar que o autor persegue quando busca algo em Pernambuco, porque se trata de algo mais do que o já sabido, para se inscrever naquilo que é sabido pelo autor e que se faz eletivo à sua expressão. Tal eleição é a marca de sua busca, porque ele se presume capaz de referendar toda a sua prática poética em seu valor simbólico, porquanto guarda registros históricos que são atualizados, para serem referidos e ressignificados por outros, a quem necessariamente não interessa aquela história, mas que pode tê-la como um valor. Se não pela sua estrutura narrativa, que é desdobrada pelo poeta, ao menos pelo exercício de escrita de que foi objeto a pena do autor. Menos pela referência que guarda do que pela engenhosidade do 
discurso que a enfeixa, cujo sentido haverá de ser tributário da referência, a que retorna, atualiza e resguarda como um bem a ser cultuado, ainda que no plano exclusivo e limitado da literatura. Incapaz de interferir na vida social, precária e comezinha, esse é o desejo interdito que o anima, mesmo sabendo se tratar de uma impossibilidade. E é essa contradição básica que move a escritura de João Cabral de Melo Neto, esteja materializada em poemas ou opúsculos, não sem razão.

Como o sujeito João Cabral de Melo Neto não é uno nem indiviso, sua descrição de Pernambuco pode ser lida em várias matizes, sejam de colorações nacionais, regionais, estaduais ou simplesmente como traço distintivo da expressão do autor, cujo nome se enreda em famílias tradicionais pernambucanas, para as quais as referências espaciais de outrora se vincam numa representação que ultrapassa a literária. Representação literária que não deixa de ser um espaço de ilustração do Pernambuco que se quis e do que dele se fez, da colonização aos nossos dias, porque se apresenta devastado e depauperado em demasia, tal como o poeta não cansou de cantar antiliricamente como uma metonímia do país na década de 1950, quando foi acometido por um surto criativo que desencadeou a publicação de obras como $O$ cão sem plumas, $O$ Rio e Morte e vida severina, mas não deixou de repercutir na década de 1980, sob outra tonalidade discursiva, na qual ecoa a primeira como uma imagem reflexa e subterrânea à referência daquele mundo e da própria forma que o representa.

\title{
POSSESSIO SPEECH OF A POET-DIPLOMAT IN BRAZILIAN ACADEMY OF LETTERS AND OTHERS BOOKLETS
}

\begin{abstract}
In 1969, João Cabral de Melo Neto took possession in the Brazilian Academy of letters with a speech on the prose of his predecessor in the Chair 37, under the title "Elogio a Assis Chateaubriand". From this writing, it is intended to describe something about the Brazilian cultural and literary life, considering the social places occupied by the author whereas diplomat and academic, mediated by personal or familiar relationships that he deprived. Similarly, it will be highlighted information from that text in order to explore relations between social life and literary form, taking into account their thematic and stylistic elections, as well as their understanding of the literary development, notably the Brazilian modernism. To do so, other textual modes will be triggered, as a counterpoint or apparatus of the possession speech, namely, letters, prefaces or poet's little-known booklets that can broaden the understanding of his work, illustrated by the poem "Vicente Yañez Pinzón".
\end{abstract}

Keywords: João Cabral de Melo Neto; literary life; liminal writings. 
O discurso de posse de um poeta-diplomata na Academia Brasileira de Letras... - 304

\section{REFERÊNCIAS}

BANDEIRA, Manuel. Correspondência de Cabral com Bandeira e Drummond. In: MELO NETO, João Cabral de. Correspondência de Cabral com Bandeira e Drummond. Org. Flora Süssekind. Rio de Janeiro: Nova Fronteira/ Fundação Casa de Rui Barbosa, 2001.

CASTELLO, José. João Cabral de Melo Neto: o homem sem alma; diário de tudo. Rio de Janeiro: Bertrand Brasil, 2006.

MELO NETO, João Cabral de. Guararapes: discurso pronunciado pelo embaixador João Cabral de Melo Neto no Monte dos Guararapes. Recife: Secretaria de Turismo, Cultura e Esportes, 1981.

MELO NETO, João Cabral de. Prefácio. In: Pernambuco: imagens do Nordeste. Rio de Janeiro: Salamandra Editorial, 1988, pp. 5-7.

MELO NETO, João Cabral de. Correspondência de Cabral com Bandeira e Drummond. Rio de Janeiro: Nova Fronteira/ Fundação Casa de Rui Barbosa, 2001.

MELO NETO, João Cabral de. Poesia completa e prosa. 2. ed. Rio de Janeiro: Nova Aguilar, 2008.

VILAÇA, Alcides. Expansão e limite na poesia de João Cabral. In: BOSI, Alfredo. Leitura de poesia. São Paulo: Ática, 1993, pp. 141-169. 